\title{
Potential of diatomaceous earth as a management tool against Acanthoscelides obtectus infestations
}

\author{
Potencial de tierra de diatomeas como una herramienta de manejo \\ contra las infestaciones de Acanthoscelides obtectus
}

Luis O. Viteri Jumbo ${ }^{1}$, Marco A. G. Pimentel ${ }^{2}$, Eugênio E. Oliveira ${ }^{3}$, Pedro F. S. Toledo ${ }^{4}$, Lêda Rita D’Antonino Faroni ${ }^{5}$

\begin{abstract}
ARTICLE DATA
Dr. Departamento de Entomologia, Universidade Federal de Viçosa. Viçosa, Brasil, luis.jumbo@ufv. br

2 Dr. Embrapa Milho e Sorgo. Sete Lagoas, Minas Gerais, Brasil, marco.pimentel@embrapa.br.

3 Dr. Departamento de Entomologia, Universidade Federal de Viçosa, Viçosa, MG, Brazil, eugenio@ ufv.br

4 M.Sc. Universidade Federal de Viçosa, Viçosa, Minas Gerais, Brasil, pedro.toledo@ufv.br

5 Dr. Departamento de Engenharia Agrícola, Universidade Federal de Viçosa, Viçosa, MG, Brazil, lfaroni@ufv.br.
\end{abstract}

Cite: Jumbo, L., Pimentel, M., Oliveira, E., Toledo, P. \& Faroni, L.R. (2019). Potential of diatomaceous earth as a management tool against Acanthoscelides obtectus infestations. Revista de Ciencias Agrícolas. 36(E): 4251. doi: https://doi.org/10.22267/rcia.1936E.105

Received: Jun 022019.

Accepted: July 172019.

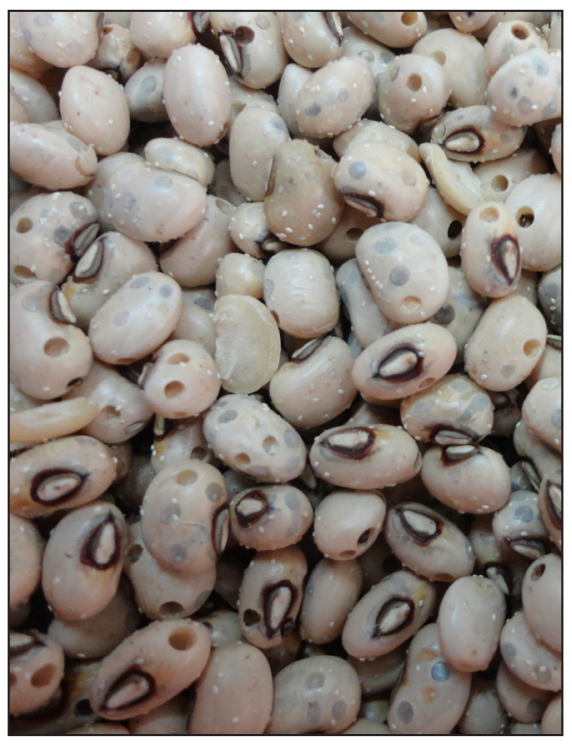

ABSTRACT

The weevil Acanthoscelides obtectus (Say) (Coleoptera: Chrysomelidae: Bruchinae) is a cosmopolitan pest that causes high losses in stored beans in small storage units and especially on-farm storages. Here, it was tested the efficacy of the inert dust diatomaceous earth (DE) as an alternative to control A. obtectus in common beans (i.e., Phaseolus vulgaris L.) on different storage temperatures and exposure intervals. Using a Completely Randomized design four doses $\left(0.25,0.50,0.75\right.$ and $\left.1.00 \mathrm{~g} \mathrm{~kg}^{-1}\right)$ of diatomaceous earth on beans kept at different temperatures $\left(25,28,30,32\right.$ and $\left.35^{\circ} \mathrm{C}\right)$. Insect mortality was evaluated after two or five days of exposure. The impacts of diatomaceous earth in the offspring of five days-exposed $A$. obtectus adults were evaluated. The offspring production (emerged adults) was evaluated 60 days after the exposure. The results revealed that A. obtectus mortality caused by diatomaceous earth was dose, temperature and exposure period dependent. For instance, at the lowest temperature $\left(25^{\circ} \mathrm{C}\right)$, diatomaceous earth dose $(0.25 \mathrm{~g}$ $\mathrm{kg}^{-1}$ of beans) and exposure period of two days, the efficacy of diatomaceous earth was significantly reduced when compared to the other treatments. When applied at temperatures above $30^{\circ} \mathrm{C}$, the diatomaceous earth treatments always resulted in A. obtectus mortality of at least $90 \%$. Curiously, offspring production (F1) was reduced to over 95\% in all diatomaceous earth, temperatures and exposure period treatments. Therefore, the results demonstrated that diatomaceous earth has the potential to be used as a tool to manage A. obtectus infestations in stored beans, considering that such control practice adequately reduced these insect infestations in several possible scenarios.

Keywords: inert dust, Phaseolus vulgaris, bean weevil control, biorational pest management.

\section{RESUMEN}

El gorgojo Acanthoscelides obtectus (Say) (Coleoptera: Chrysomelidae: Bruchinae) es una plaga cosmopolita que causa grandes pérdidas en frijoles almacenados, ya sea em pequenas unidades o en fincas. Aquí, se probó la eficacia del polvo inerte de la tierra de diatomeas (DE) como una alternativa para controlar A. obtectus en frijoles comunes Phaseolus vulgaris L., en diferentes temperaturas de almacenamiento e intervalos de exposición. Usando un

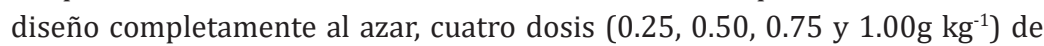
tierra de diatomeas en frijoles mantenidos a diferentes temperaturas $(25,28$, 30,32 y $35^{\circ} \mathrm{C}$ ). La mortalidad de los insectos se evaluó después de dos o cinco días de exposición. Se evaluaron los impactos de la tierra de diatomeas en la 


\begin{abstract}
descendencia de adultos de A. obtectus expuestos a cinco días. La producción de descendencia (adultos emergentes) se evaluó 60 días después de la exposición. Los resultados mostraron que la mortalidad por A. obtectus causada por la tierra de diatomeas dependía de la dosis, la temperatura y el período de exposición. Por ejemplo, a la temperatura más baja $\left(25^{\circ} \mathrm{C}\right)$, la dosis de tierra de diatomeas $\left(0.25 \mathrm{~g} \mathrm{~kg}^{-1}\right.$ de frijoles) y el período de exposición de dos días, la eficacia de la tierra de diatomeas se redujo significativamente en comparación con los otros tratamientos. Cuando se aplica a temperaturas superiores a $30^{\circ} \mathrm{C}$, los tratamientos con tierra de diatomeas siempre dieron como resultado una mortalidad de A. obtectus de al menos 90\%. Curiosamente, la producción de descendencia (F1) se redujo a más del 95\% en todos los tratamientos de tierra de diatomeas, temperaturas y períodos de exposición. Por lo tanto, los resultados demostraron que la tierra de diatomeas tiene el potencial de ser utilizada como una herramienta para controlar las infestaciones de A. obtectus en frijoles almacenados, considerando que dicha práctica de control redujo adecuadamente estas infestaciones de insectos en varios escenarios posibles.
\end{abstract}

Palabras clave: polvo inerte, Phaseolus vulgaris, control del gorgojo del frijol, manejo bioracional de plagas.

\section{INTRODUCTION}

The bean weevil Acanthoscelides obtectus (Say) (Coleoptera: Chrysomelidae: Bruchinae) is one of the most important pests of many plants from the Fabaceae family, especially the common beans Phaseolus vulgaris (Lineu). Their high reproductive potential and short life cycle allow them to produce several generations within a year, especially under favorable conditions (Soares et al., 2015). The attack of $A$. obtectus in bean grains begins when they are still in the field and subsequently they are able to infest storage units causing losses ranging from 7 to $40 \%$, which corresponds to $1.59-9.12$ millions of tons each year in the world caused by bruchids (Mbogo et al., 2009; Jiménez et al., 2017). The losses caused by A. obtectus is a serious threat to the major protein source of hundreds of millions of people, especially those from Latin America, Asia and Africa ( Zaugg et al., 2013; Hnatuszko-Konka et al., 2014; Pitura and Arntfield, 2019).

The commonly used strategies to control A. obtectus on small and large stored grain units rely on protectant and fumigant insecticides. However, the indiscriminate use of these products have constantly been questioned, since their use is normally associated with serious problems, such the selection of resistant populations (Pimentel et al., 2007; Boyer et al., 2012; Haddi et al., 2018), environmental pollution (Stehle and Schulz, 2015; Tang et al., 2018) and impacts on the human health (Bjørling-Poulsen et al., 2008; Radwan et al., 2015; Chen et al., 2016). Because of these backlashes, the investigation of new products that are less persistent in the environmental and less harmful to other organisms is of extreme importance. Among these alternatives, mechanical control, essential oils, inert dusts or combinations of them have been demonstrated to be effective to control the weevils that attack bean grains (Papachristos and Stamopoulos, 2004; Badii et al., 2014; Viteri Jumbo et al., 2018; González Armijos et al., 2019; Rodríguez-González et al., 2019), including A. obtectus (Bohinc et al., 2013; Freitas et al., 2016; Viteri Jumbo et al., 2018).

Diatomaceous earths (DEs) are natural inert materials derived from fossilized geological deposits of siliceous; and mainly made of silicon dioxide (Korunic, 1997; Cook et al., 2008). Additionally, the effectiveness of diatomaceous earth as protectants of different stored beans against their major pests has been already demonstrated (Prasantha et al., 2003; Stathers et al., 2004; Bohinc et al., 
2013; Badii et al., 2014). The mode of action of diatomaceous earth is by damaging the insect's tegument surface (including sensilla and pores) culminating in reduction of body water content and death through desiccation (Korunićetal., 2016; Subramanyam and Roesli, 2000). Besides being relatively easy to apply, diatomaceous earth toxicity to mammalians is considered low because this chemically unreactive powder is mainly composed by silica, which does not accumulate in mammals as such molecules are excreted in the urine (Korunic, 2013). Additionally, diatomaceous earth does not break down (degrade) rapidly and do not affect end-use quality of grains (Subramanyam and Roesli, 2000; Stathers et al., 2004; Korunic, 2013).

The insecticidal efficacy of diatomaceous earth may be affected by abiotic factors e.g., temperature and exposure period or biotic factors e.g., insect species, physiology, and behavior, especially in tropical climate conditions. Thus, this study was conducted aiming to determine whether the exposure period and temperatures levels would affect the efficacy of diatomaceous earth against $A$. obtectus.

\section{MATERIALS AND METHODS}

Insect rearing and diatomaceous earth formulation. Adults of $A$. obtectus were maintained under controlled conditions (temperature $27 \pm 1^{\circ} \mathrm{C}$, relative humidity $65 \pm$ $5 \%$ and $12 \mathrm{~h}$ of scotophase) on common beans (Phaseolus vulgaris cv Ouro Negro). Newly emerged $(<48 \mathrm{~h})$ unsexed adults were used in all the experiments. These insect colonies were reared under controlled conditions and in an insecticide-free environment for at least one year. We used the diatomaceous earth formulation Keepdry ${ }^{\mathrm{TM}}$ (Irrigação Dias
Cruz Ltda., Santo André, SP, Brazil) which is a diatomaceous earth formulation of freshwater origin containing $86 \%$ of silicon dioxide and $14 \%$ inert ingredients. The formulation was stored in the dark for three weeks inside sealed plastic bags at $25^{\circ} \mathrm{C}$ until the beginning of the experiments.

Bioassays toxicity of diatomaceous earth in different temperatures. To evaluate the susceptibility of $A$. obtectus to diatomaceous earth (DE) the experimental design was Completely Randomized. Four doses of Keepdry ${ }^{\mathrm{TM}}$ which are lower than the recommended field rate $(0.25,0.50,0.75$ and $1.00 \mathrm{~g} \mathrm{~kg}-1$ of beans) were tested under different temperature conditions $(25,28$, 30,32 or $35^{\circ} \mathrm{C}$ ) and exposure periods (two and five days). Three replicates were used for each dose, temperature, exposure period and a control treatment (grains without DE application) was used for each bioassay. In order to homogenize the DE with the bean grains, the diatomaceous earth amounts were added to a glass jar (2.0L of volume capacity) containing $150 \mathrm{~g}$ of bean grains. After the application, the jars were rolled manually for 60 seconds. Subsequently, bean grain masses (45g) were placed inside Petri dishes $(45 \mathrm{~cm}$ diameter) and 25 newly emerged unsexed adults of $A$. obtectus were transferred into the Petri dishes. After the exposure periods, the insects were considered dead when unable of walking or flying when touched with fine brush pods.

Effects of diatomaceous earth on the offspring production of $A$. obtectus. To evaluate the impacts of DE in the offspring production of $A$. obtectus, the samples that stayed exposed for five days were maintained after mortality had been assessed. All insects (dead or alive) were removed from the bean 
grain masses, and the Petri dishes with grains remained in the incubators for an additional period of 60 days. After this period, the number of emerged adults (F1) was recorded and the reduction in progeny or inhibition rate (\%IR) was calculated as:

$$
\% I R=\frac{C n-T n}{C n} * 100
$$

Where $\mathrm{Cn}$ is the number of newly emerged insects in the untreated jar and $T n$ is the number of insects emerged in the treated jar (Tapondjou et al., 2002; Rajashekar et al., 2010). Three replicates were used for each treatment.

Data analysis. In order to test the effects and the interactions of temperature, dose and exposure interval in the mortality and progeny production of $A$. obtectus, the data was submitted to three-way Analysis of Variance (ANOVA). Mortality was analyzed using one-way ANOVA to determine significant differences $(P<0.05)$ among exposure times. Means were separated by Duncan's multiple range test at $P<0.05$. The same procedure was followed to analyze for the effects of diatomaceous earth (DE) treatment on the progeny production of $A$. obtectus.

\section{RESULTS AND DISCUSSION}

The Analysis of Variance revealed that temperature, doses, and exposure periods and the associated interactions between them were highly significant $(P<0.0001)$ for the DE efficacy against $A$. obtectus (Table 1). Similar results were obtained for the reduction of $A$. obtectus progeny in bean grain masses that were treated with DE (Table 1).

Table 1. ANOVA for main effects and interactions of mortality and progeny production of Acanthoscelides obtectus after being exposed to diatomaceous earth-treated beans.

\begin{tabular}{lccccccc}
\hline \multirow{1}{*}{ Source of variation } & \multicolumn{3}{c}{ Mortality } & \multicolumn{3}{c}{ Progeny production } \\
\cline { 2 - 8 } & & $\boldsymbol{D . F}$ & $\boldsymbol{F}$ & $\boldsymbol{P}$ & $\boldsymbol{D}$.F & $\boldsymbol{F}$ & $\boldsymbol{P}$ \\
\hline Model & 49 & 63.14 & $<0.0001$ & 24 & 207.17 & $<0.0001$ \\
Error & 100 & & & 50 & & \\
Temperature & 4 & 347.31 & $<0.0001$ & 4 & 83.23 & $<0.0001$ \\
Dose & 4 & 293.81 & $<0.0001$ & 4 & 856.77 & $<0.0001$ \\
Exposure interval & 1 & 95.52 & $<0.0001$ & - & - & - \\
Temperature $\times$ Dose & 16 & 7.82 & $<0.0001$ & 16 & 75.75 & $<0.0001$ \\
Temperature $\times$ Exposure interval & 4 & 53.95 & $<0.0001$ & - & - & - \\
Dose $\times$ Exposure interval & 4 & 6.13 & $<0.0001$ & - & - & - \\
Temperature $\times$ Dose $\times$ Exposure interval & 16 & 4.27 & $<0.0001$ & - & - & - \\
\hline
\end{tabular}

$\mathrm{DF}=$ Degree of Freedom, $\mathrm{F}=$ test $\mathrm{F}, \mathrm{P}=\mathrm{P}(<0.05)$ 
The $A$. obtectus mortality caused by DE revealed to be doses, temperature, and exposure period dependent. When the exposure period was of two days, the bean weevils kept at 25 and $28^{\circ} \mathrm{C}$ exhibited mortality levels of at least $50 \%$ in all treatments, excepting the mortality recorded for the treatment of $0.25 \mathrm{~g} \mathrm{~kg}^{-1}$ at $25^{\circ} \mathrm{C}$, where there was no significant difference when compared with the A. obtectus mortality obtained for diatomaceous earth-untreated beans. For temperature treatments above $30^{\circ} \mathrm{C}$, the $A$. obtectus mortality did not differ between treatments, being always superior to $90 \%$ (Figure 1A). The mortality results obtained for the exposure period of five days showed that $A$. obtectus were very susceptible to diatomaceous earth exposure (Figure 1B). For instance, event at lower diatomaceous earth doses and temperatures, the mortality level obtained were never below $40 \%$, resulting in significant differences when compared with the mortality recorded for $A$. obtectus reared on untreated bean masses (Figure 1B).
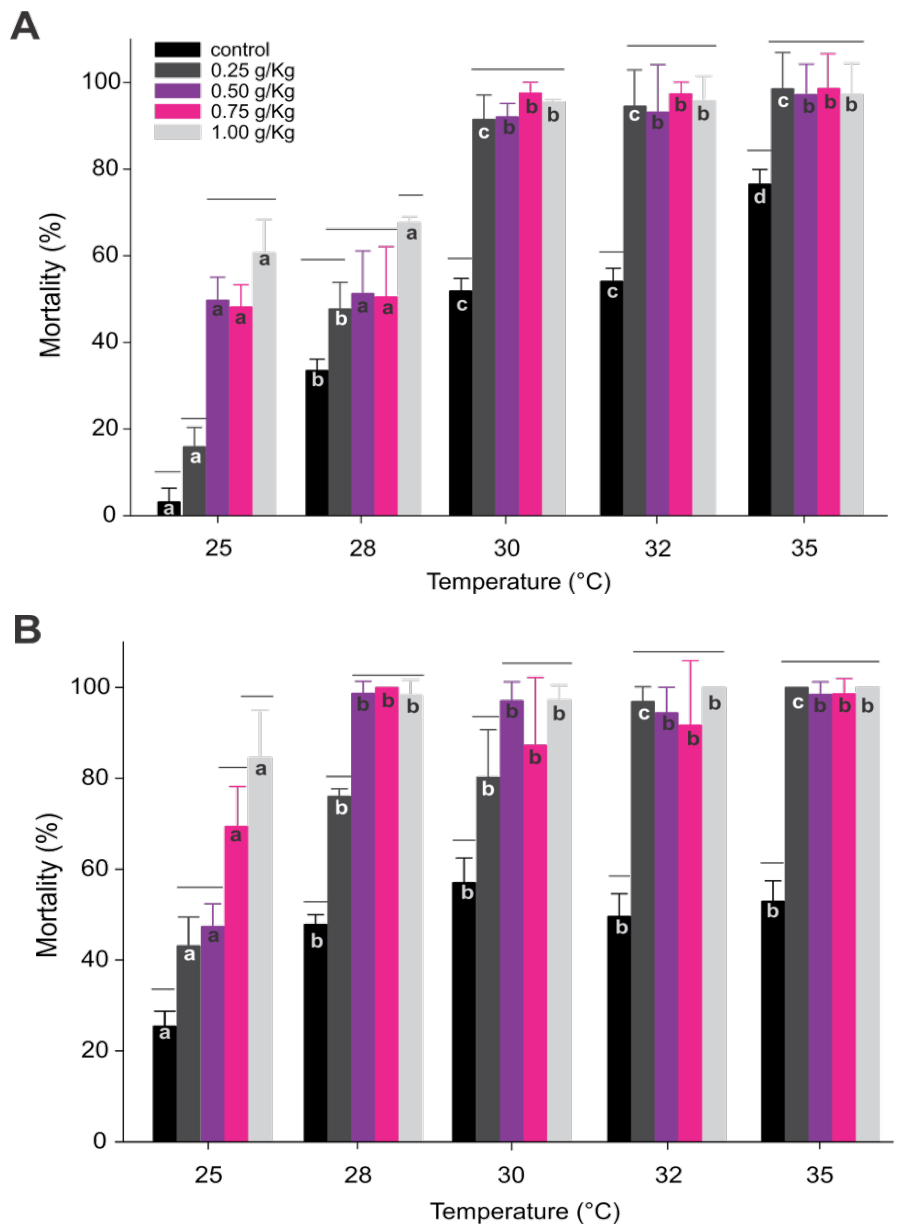

Bars grouped under the same horizontal line do not present significant differences $(P>0.05)$. Histograms of a particular color grouped by similar letters across the different temperatures do not present significant differences (Duncan's multiple range test, $\mathrm{P}>0.05$ ).

Figure 1. Mortality levels of $A$. obtectus when exposed for two $(A)$ and five $(B)$ days to different diatomaceous earth doses and temperature conditions. 
Results obtained for the progeny production showed that the DE caused significant reductions in the progeny of $A$. obtectus. Even at the lowest diatomaceous earth doses tested $\left(0.25 \mathrm{~g} \mathrm{~kg}^{-1}\right)$ exposed to $25^{\circ} \mathrm{C}$, the suppression of progeny production was above $90 \%$ (Table 2). Increase of temperature also affected the number of $A$. obtectus adults emerged of diatomaceous earth non-treated bean grain masses, where the average number of individuals of $96.0 \pm 10.5,106.0 \pm 8.4,67.7 \pm$ $11.2,30.3 \pm 5.3,10.0 \pm 1.9$ when exposed to $25,28,30,32$ and $35^{\circ} \mathrm{C}$, respectively.

In the present study, it was evaluated the efficacy of diatomaceous earth to control A. obtectus and the contributions of dose, temperature and exposure interval on the efficacy of this inert dust. The results showed that all the doses of DE were toxic to A. obtectus adults and there is a positive correlation between mortality and dose, temperature and exposure period. Such increased mortality rates within exposure time increase are due to the slow-acting mode of action of DE products which are different from traditional grain protectants that may kill insects faster (Korunic, 1998).

Diatomaceous earth is an inert dust mostly composed by small silica particles that are able to abrade the insect cuticle and absorb water, which potentially leads to insect death due to dehydration (Korunic, 1998; Subramanyam and Roesli, 2000). Since adults of $A$. obtectus do not feed, it is difficult to recover the water loss caused by DE, which increases the susceptibility of these insects to diatomaceous earth exposures. Moreover, higher temperatures usually increase insect movement inside the grains, causing increased contact with the diatomaceous earth and, consequently, greater cuticular damage. Furthermore, it is important to feature that unlike synthetic insecticides, DE is inert and does not degrade with the increase of temperature, which allow farmers to use DE products combined with elevated temperatures (Dowdy, 1999; Fields and Korunic, 2000; Athanassiou et al., 2005; Athanassiou et al., 2011; Bohinc et al., 2013; Frederick and Subramanyam 2016).

Table 2. Progeny reductions (\%) of $A$. obtectus that were subjected (during five days) to diatomaceous earth-treated bean grain masses kept at different temperatures.

\begin{tabular}{|c|c|c|c|c|c|}
\hline \multirow{2}{*}{$\begin{array}{c}\text { Dose } \\
\left(\mathrm{g} \mathrm{kg}^{-1}\right)\end{array}$} & \multicolumn{5}{|c|}{ Progeny reduction (\%) } \\
\hline & $25^{\circ} \mathrm{C}$ & $28^{\circ} \mathrm{C}$ & $30{ }^{\circ} \mathrm{C}$ & $32^{\circ} \mathrm{C}$ & $35^{\circ} \mathrm{C}$ \\
\hline 0.25 & $95.0 \pm 0.2 \mathrm{aB}$ & $99.0 \pm 0.01 \mathrm{bA}$ & $100 \mathrm{bA}$ & $100 \mathrm{bA}$ & $100 \mathrm{bA}$ \\
\hline 0.50 & $99.0 \pm 0.07 \mathrm{aA}$ & $100 \mathrm{aA}$ & $100 \mathrm{aA}$ & $100 \mathrm{aA}$ & $100 \mathrm{aA}$ \\
\hline 0.75 & $100 \mathrm{~A}$ & $100 \mathrm{~A}$ & $100 \mathrm{~A}$ & $100 \mathrm{~A}$ & $100 \mathrm{~A}$ \\
\hline 1.00 & $100 \mathrm{~A}$ & $100 \mathrm{~A}$ & $100 \mathrm{~A}$ & $100 \mathrm{~A}$ & $100 \mathrm{~A}$ \\
\hline
\end{tabular}

Values in the same row followed by different lowercase letter are significantly different when exposed to different temperatures; Similar capital letters on the same column indicate no significant differences between treatments (Duncan's multiple range $\left(P<0.05 ; d f_{(4,14)}\right)$ was 19.36 for columns and rows). 
Although treatments that caused high $A$. obtectus mortality resulted in severe progeny reduction, similar reductions were observed in the exposure to lower diatomaceous earth doses, where there were considerably more insects alive. The reasons underlying the aforementioned progeny reduction may potentially be related to the accumulation of diatomaceous earth particles on the ovipositor of $A$. obtectus females, acting as a physical barrier and disturbing reproduction behaviors (Szentesi, 1976). Furthermore, such progeny reductions may also be attributed to the physiological costs of directing energy to the repairment of damaged cuticle aiming to minimize water losses (Subramanyam and Roesli, 2000; Prasantha et al., 2002; Prasantha et al., 2015). Additionally, diatomaceous earth could also have affected the egg hatching or newly emerged larvae. As A. obtectus females lay their eggs freely in the grain masses, the newly emerged larvae generally take few hours selecting and perforating their hosts, which may increase their potential exposure DE particles left on the bean grains (Simmonds et al., 1989; Thiéry et al., 1994).

Considering that higher doses of diatomaceous earth ( $>0.3 \mathrm{~g} \mathrm{~kg}^{-1}$ ) are no longer acceptable since they cause negative effects on the grain physical proprieties (causing dusty appearance) and because of the difficulties associated to their sprayed application.(Korunic, 1998; Subramanyam and Roesli, 2000). Thus, the results showed that lower DE doses as $0.25 \mathrm{~g} \mathrm{~kg}^{-1}$ of are sufficient to control $A$. obtectus infestation in bean grain masses in several potential scenarios, without affecting the quality of grains, which reinforce the potential of these inert dust to be used as sustainable alternatives for protecting bean grain masses during on-farm storage phases.

\section{CONCLUSIONS}

Diatomaceous earth is a potential alternative to the control of $A$. obtectus; the mortality of adult weevils was dependent of both temperature and exposure period. Additionally, diatomaceous earth significantly reduced the offspring production (F1) of $A$. obtectus, regardless of dose and temperature, which makes DE a good candidate to be integrated on management strategies of these bean weevils, especially on small storage units.

\section{ACKNOWLEDGMENTS}

This study was financed in part by the Coordenação de Aperfeiçoamento de Pessoal de Nível Superior - Brasil (CAPES) - Finance Code 001. The authors would like to thank the National Council of Scientific and Technological Development (CNPq) and Minas Gerais State Foundation for Research Aid (FAPEMIG) for funding. Funding was also provided by the Secretaría Nacional de Educación Superior Ciencia y Tecnología of Ecuador (SENESCYT-Ecuador).

Conflict of interest: The authors declare that there is no conflict of interest.

\section{BIBLIOGRAPHIC REFERENCES}

Athanassiou C, Vayias B, Dimizas C, Kavallieratos N, Papagregoriou A. \& Buchelos CT. (2005). Insecticidal efficacy of diatomaceous earth against Sitophilus oryzae (L.)(Coleoptera: Curculionidae) and Tribolium confusum du Val (Coleoptera: Tenebrionidae) on stored wheat: influence of dose rate, temperature and exposure interval. Journal of Stored Products Research. 41(1):47-55. doi: 10.1016/j. jspr.2003.12.001 
Athanassiou CG, Kavallieratos NG, Vayias BJ, Tomanović Ž, Petrović A, Rozman V, Adler C, Korunic Z. \& Milovanović, D. (2011). Laboratory evaluation of diatomaceous earth deposits mined from several locations in central and southeastern Europe as potential protectants against coleopteran grain pests. Crop protection 30(3):329-339. doi: 10.1016/j. cropro.2010.10.004

Badii, BK, Adarkwah, C, Obeng-Ofori D. \& Ulrichs, C. (2014). Efficacy of diatomaceous earth formulations against Callosobruchus maculatus (F.)(Coleoptera: Bruchidae) in Kersting's groundnut (Macrotyloma geocarpum Harms): influence of dosage rate and relative humidity. Journal of pest science. 87(2):285-294. doi: 10.1007/s10340-013-0548-0

Bjørling-Poulsen, M. Andersen, HR. \& Grandjean, P. (2008). Potential developmental neurotoxicity of pesticides used in Europe. Environmental Health. 7:50. doi: 10.1186/1476-069X-7-50

Bohinc, T., Vayias, B., Bartol, T. \& Trdan, S. (2013). Assessment of insecticidal efficacy of diatomaceous earth and powders of common lavender and field horsetail against bean weevil adults. Neotropical entomology. 42(6): 642-648. doi: 10.1007/s13744-013-0168-7

Boyer, S., Zhang, H. \& Lempérière G. (2012). A review of control methods and resistance mechanisms in stored-product insects. Bulletin of entomological research. 102(2): 213-229. doi: $10.1017 / \mathrm{S} 0007485311000654$

Chen, S., Gu, S., Wang, Y., Yao, Y., Wang, G., Jin, Y. \& Wu, Y. (2016). Exposure to pyrethroid pesticides and the risk of childhood brain tumors in East China. Environmental pollution 218:11281134. doi: 10.1016/j.envpol.2016.08.066

Cook, DA, Wakefield, ME. \& Bryning, GP. (2008). The physical action of three diatomaceous earths against the cuticle of the flour mite Acarus siro L.(Acari: Acaridae). Pest Management Science: formerly Pesticide Science. 64:141-146. doi: https://doi.org/10.1002/ps.1484
Dowdy, AK. (1999). Mortality of red flour beetle, Tribolium castaneum (Coleoptera: Tenebrionidae) exposed to high temperature and diatomaceous earth combinations. Journal of Stored Products Research. 35(2):175182. doi: https://doi.org/10.1016/S0022474X(98)00043-5

Fields, P. \& Korunic, Z. (2000). The effect of grain moisture content and temperature on the efficacy of diatomaceous earths from different geographical locations against stored-product beetles. Journal of Stored Products Research. 36(1): 1-13. doi: https://doi.org/10.1016/ S0022-474X(99)00021-1

Frederick,JL.\& Subramanyam, B. (2016). Influence of temperature and application rate on efficacy of a diatomaceous earth formulation against Tribolium castaneum adults. Journal of Stored Products Research. 69: 86-90. doi: https://doi. org/10.1016/j.jspr.2016.06.009

Freitas, R.S., Faroni, L.R.A. \& Sousa, A.H. (2016). Hermetic storage for control of common bean weevil, Acanthoscelides obtectus (Say). Journal of Stored Products Research. 66: 1-5. doi: https://doi.org/10.1016/j.jspr.2015.12.004

González Armijos, M.J., Viteri Jumbo, L.O., Faroni, L.R., Oliveira, E.E., Flores, A.F., Heleno, F.F. \& Haddi, K. (2019). Fumigant toxicity of eugenol and its negative effects on biological developmente of Callosobruchus maculatus L. Revista de Ciencias Agrícolas. 36(1):5-15. doi:http://dx.doi.org/10.22267/ rcia.193601.94

Haddi, K., Valbon, W.R., Viteri Jumbo, L.O., De Oliveira, L.O., Guedes, R.N.C, \& Oliveira E.E. (2018). Diversity and convergence of mechanisms involved in pyrethroid resistance in the stored grain weevils, Sitophilus spp. Scientific Reports. 8: 16361. doi: https://doi. org/10.1038/s41598-018-34513-5

Hnatuszko-Konka, K., Kowalczyk, T., Gerszberg, A., Wiktorek-Smagur, A. \& Kononowicz AK. (2014). Phaseolus vulgaris - Recalcitrant potential. Biotechnology Advances. 32(7): 1205-1215. doi: https://doi.org/10.1016/j. biotechadv.2014.06.001 
Jiménez, J.C, de la Fuente, M., Ordás, B., García Domínguez, L.E. \& Malvar, R.A. (2017). Resistance categories to Acanthoscelides obtectus (Coleoptera: Bruchidae) in tepary bean (Phaseolus acutifolius), new sources of resistance for dry bean (Phaseolus vulgaris) breeding. Crop protection. 98:255266. doi: https://doi.org/10.1016/j. cropro.2017.04.011

Korunic, Z. (1997). Rapid assessment of the insecticidal value of diatomaceous earths without conducting bioassays. Journal of Stored Products Research. 33(3): 219229. doi: https://doi.org/10.1016/S0022474X(97)00004-0

Korunić, Z., Rozman, V., Liška, A., \& Lucić, P. J. P. A. (2016). A review of natural insecticides based on diatomaceous earths. 22(1): 10-18. doi: http://dx.doi.org/10.18047/poljo.22.1.2

Korunic, Z. (2013). Diatomaceous earths: Natural insecticides. Pesticidi i fitomedicina. 28(2):77-95. doi: https://doi.org/10.2298/ PIF1302077K

Mbogo, K., Davis, J. \& Myers, J. (2009). Transfer of the arcelin-phytohaemagglutinin- $\alpha$ amylase inhibitor seed protein locus from tepary bean (Phaseolus acutifolius A. Gray) to common bean (P. vulgaris L.). Biotechnology. 8:285-295. doi: 10.3923/biotech.2009.285.295

Papachristos, D.P. \& Stamopoulos, D.C. (2004). Fumigant toxicity of three essential oils on the eggs of Acanthoscelides obtectus (Say) (Coleoptera: Bruchidae). Journal of Stored Products Research. 40(5): 517-525. doi: https://doi.org/10.1016/j.jspr.2003.07.002

Pimentel, M.A.G., Faroni, L.R.D.A., Tótola, M.R. \& Guedes, R.N.C. (2007). Phosphine resistance, respiration rate and fitness consequences in stored-product insects. Pest Management Science. 63:876-881. doi: https://doi. org/10.1002/ps.1416

Pitura, K. \& Arntfield, S.D. (2019). Characteristics of flavonol glycosides in bean (Phaseolus vulgaris L.) seed coats. Food Chemistry. 272:26-32. doi: https://doi.org/10.1016/j. foodchem.2018.07.220.
Prasantha, B.D.R., Reichmuth, Ch. \& Büttner, C. (2003). Effect of diatomaceous earths on the reproductivity of Callosobruchus maculatus (Fabricius) (Coleoptera: Bruchidae); biology, detection and biological control. In: Credlan, P.E., Armitage, D.M., Bell, C.H., Cogan, P.M., Highley, E. (Eds.). Advances in Stored Product Protection. Proceedings of 8th International Working Conference on Stored Product Protection, 22-26 July 2002, York, UK.

Prasantha, B.D.R., Reichmuth, Ch., Hetz, S.K. \& Adler, C. (2002). Physiological aspects of diatomaceous earth treated cowpea wevil Callosobruchus maculatus (F.) (Coleoptera: Bruchidae); chemical and physical control. In: Credlan, P.E., Armitage, D.M., Bell, C.H., Cogan, P.M., Highley, E. (Eds.), Advances in Stored Product Protection. Proceedings of 8th International Working Conference on Stored Product Protection, 22-26 July 2002, York, UK.

Prasantha, BR., Reichmuth, C., Adler, C. \& Felgentreu, D. (2015). Lipid adsorption of diatomaceous earths and increased water permeaility in the epicuticle layer of the cowpea weevil Callosobruchus maculatus (F.) and the bean weevil Acanthoscelides obtectus (Say) (Chrysomelidae). Journal of Stored Products Research, 64:36-41. doi: https://doi. org/10.1016/j.jspr.2015.08.003

Radwan, M., Jurewicz, J., Wielgomas, B., Piskunowicz, M., Sobala, W., Radwan, P., Jakubowski, L., Hawuła, W. \& Hanke, W. (2015). The association between environmental exposure to pyrethroids and sperm aneuploidy. Chemosphere 128:42-48. doi: https://doi. org/10.1016/j.chemosphere.2014.12.077

Rajashekar, Y, Gunasekaran, N. \& Shivanandappa, T. (2010). Insecticidal activity of the root extract of Decalepis hamiltonii against storedproduct insect pests and its application in grain protection. Journal of Food Science and Technology 47:310-314. doi: https://doi. org/10.1007/s13197-010-0049-6 
Rodríguez-González, Á., Álvarez-García, S., González-López, Ó., Da Silva, F. \& Casquero, P.A. (2019). Insecticidal Properties of Ocimum basilicum and Cymbopogon winterianus against Acanthoscelides obtectus, Insect Pest of the Common Bean (Phaseolus vulgaris, L.). Insects, 10 (5): 151. doi: https://doi. org/10.3390/insects10050151 10:151.

Simmonds, M., Blaney, W. \& Birch, A. (1989). Legume seeds: the defences of wild and cultivated species of Phaseolus against attack by bruchid beetles. Annals of Botany 63:177-184. doi: https://doi.org/10.1093/ oxfordjournals.aob.a087721

Soares, M.A., Quintela, E.D., Mascarin, G.M. \& Arthurs, S.P. (2015). Effect of temperature on the development and feeding behavior of Acanthoscelides obtectus (Chrysomelidae: Bruchinae) on dry bean (Phaseolus vulgaris L.). Journal of Stored Products Research 61:90-96. doi: https://doi.org/10.1016/j. jspr.2014.12.005

Stathers, T., Denniff, M., \& Golob, P. (2004). The efficacy and persistence of diatomaceous earths admixed with commodity against four tropical stored product beetle pests. Journal of Stored Products Research 40:113123. doi: https://doi.org/10.1016/S0022474X(02)00083-8

Stehle, S. \& Schulz, R. (2015). Agricultural insecticides threaten surface waters at the global scale. Proceedings of the National Academy of Sciences 112:5750-5755. doi: https://doi.org/10.1073/pnas.1500232112

Subramanyam, B. \& Roesli R. (2000). Alternatives to pesticides in stored-product IPM. New York: Springer Science \& Business Media. 437p.

Szentesi, A. (1976). The Effect of the Amputation of Head Appendages on the Oviposition of the Bean Weevil, Acanthoscelides obtectus Say (Coleoptera: Bruchidae). The Host-Plant in Relation to Insect Behaviour and Reproduction: Springer, 275-281.

Tang, W., Wang, D., Wang, J., Wu, Z., Li, L., Huang, M., Xu, S. \& Yan, D. (2018). Pyrethroid pesticide residues in the global environment: An overview. Chemosphere. 191:9901007. doi: https://doi.org/10.1016/j. chemosphere.2017.10.115

Tapondjou, L., Adler, C., Bouda, H. \& Fontem, D. (2002). Efficacy of powder and essential oil from Chenopodium ambrosioides leaves as post-harvest grain protectants against sixstored product beetles. Journal of Stored Products Research. 38:395-402. doi: https:// doi.org/10.1016/S0022-474X(01)00044-3

Thiéry, D., Jarry, M. \& Pouzat J. (1994). To penetrate or not to penetrate? A behavioral choice by bean beetle first-instar larvae in response to Phaseolus vulgaris seed surface quality. Journal of Chemical Ecology. 20:1867-1875. doi: https://doi.org/10.1007/BF02066228

Viteri Jumbo, L.O., Faroni, L.R.A., Oliveira, E.E, Pimentel, M.A, \& Silva, G.N. (2014). Potential use of clove and cinnamon essential oils to control the bean weevil, Acanthoscelides obtectus Say, in small storage units. Industrial Crops and Products 56:27-34. doi: https://doi. org/10.1016/j.indcrop.2014.02.038

Viteri Jumbo, L.O, Haddi, K, Faroni, L.R.D, Heleno, F.F, Pinto, F.G. \& Oliveira, E.E. (2018). Toxicity to, oviposition and population growth impairments of Callosobruchus maculatus exposed to clove and cinnamon essential oils. PLOS ONE 13:e0207618. 10.1371/journal. pone.0207618

Zaugg, I., Magni, C., Panzeri, D., Daminati, M.G., Bollini, R., Benrey, B., Bacher, S. \& Sparvoli, F. (2013). QUES, a new Phaseolus vulgaris genotype resistant to common bean weevils, contains the Arcelin-8 allele coding for new lectin-related variants. Theoretical and Applied Genetics. 126:647-661. doi: https://doi. org/10.1007/s00122-012-2008-2 